
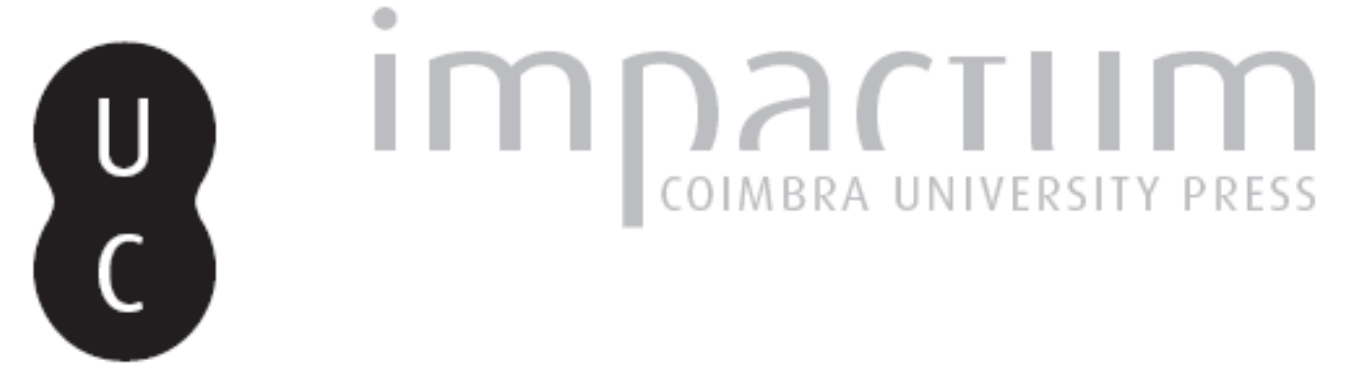

\title{
Aggregate and Sector-Specific Exchange Rate Indexes for the Portuguese Economy
}

Autor(es): $\quad$ Alexandre, Fernando; Bação, Pedro; Cerejeira, João; Portela, Miguel

Publicado por: Faculdade de Economia da Universidade de Coimbra

URL persistente:

URl:http://hdl.handle.net/10316.2/25215

DOI:

DOI:http://dx.doi.org/10.14195/2183-203X_30_1

Accessed : $\quad$ 26-Apr-2023 12:56:53

A navegação consulta e descarregamento dos títulos inseridos nas Bibliotecas Digitais UC Digitalis, UC Pombalina e UC Impactum, pressupõem a aceitação plena e sem reservas dos Termos e Condições de Uso destas Bibliotecas Digitais, disponíveis em https://digitalis.uc.pt/pt-pt/termos.

Conforme exposto nos referidos Termos e Condições de Uso, o descarregamento de títulos de acesso restrito requer uma licença válida de autorização devendo o utilizador aceder ao(s) documento(s) a partir de um endereço de IP da instituição detentora da supramencionada licença.

Ao utilizador é apenas permitido o descarregamento para uso pessoal, pelo que o emprego do(s) título(s) descarregado(s) para outro fim, designadamente comercial, carece de autorização do respetivo autor ou editor da obra.

Na medida em que todas as obras da UC Digitalis se encontram protegidas pelo Código do Direito de Autor e Direitos Conexos e demais legislação aplicável, toda a cópia, parcial ou total, deste documento, nos casos em que é legalmente admitida, deverá conter ou fazer-se acompanhar por este aviso.

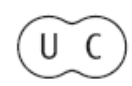


Aggregate and Sector-Specific Exchange Rate Indexes for the Portuguese Economy*

Fernando Alexandre/Pedro Bação/João Cerejeira/Miguel Portela EEGUMNIPE, FEUC/GEMF, EEGUM/NIPE, EEGUMNIPE e IZA

resumo

Neste texto apresentamos índices da taxa de câmbio efectiva, agregados e por sector, para a economia portuguesa. Os vários índices apresentados são semelhantes entre si, estando os índices sectoriais fortemente correlacionados com os índices agregados. Contudo, os índices sectoriais são mais informativos que os agregados: enquanto os índices agregados não são significativos em regressões do emprego sectorial, os índices sectoriais são significativos e revelam a existência de um efeito importante da taxa de juro sobre o emprego.

\section{résumé / abstract}

Dans ce texte on présente des indices de taux de change effectif, agrégés et sectoriels, pour l'économie portugaise. Les indices sont semblables entre eux, de façon que la corrélation entre les indices sectoriels et les indices agrégés est très forte. Cependant, les indices sectoriels sont plus informatifs que les indices agrégés: tandis que les indices agrégés ne sont pas significatifs dans les régressions pour l'emploi, les indices sectoriels sont significatifs et, en plus, leurs coefficients montrent que la taux de change a un effet important sur l'emploi.

In this paper, we compute and compare aggregate and sector-specific exchange rate indexes for the Portuguese economy. We find that alternative effective exchange rate indexes are very similar between them. We also find that sector-specific effective exchange rates are strongly correlated with aggregate indexes. Nevertheless, we show that sector-specific exchange rates are more informative than aggregate exchange rates in explaining changes in employment: whereas aggregate indexes are statistically insignificant in employment equations, regressions using sector-specific exchange rate indexes show a statistically significant and economically large effect of exchange rates on employment.

Classificação JEL: F15, F16, F41.

* The authors are very grateful to an anonymous referee for the valuable comments given on earlier versions of this paper. 
The exchange rate is commonly viewed as a policy instrument that governments (or monetary authorities) could use to improve domestic economic conditions. The fierce discussion in recent years about the possible undervaluation of the Chinese Yuan is a prominent example of the importance attached to such matters. The same sort of discussion occurred within euro area countries before they agreed to give up their national currencies and adopt a common currency.

Despite the usual focus, namely in the popular press, on bilateral nominal exchange rates, what should be a cause for concern is the evolution of the effective exchange rate, and particularly of the real effective exchange rate, i.e., a weighted index of relative prices, with weights reflecting the relevance of the trade partners. In fact, upon abandoning their national currencies, countries lose their ability to use nominal devaluations to counteract the loss of international competitiveness stemming from high domestic inflation relative to foreign competitors, and their ability to lower with a stroke of the pen the foreign prices of those domestic goods that compete on price rather than on quality. Indeed, there is evidence that fluctuations in real exchange rates may have strong inter- and within-sector reallocation effects, as they imply changes in the international relative price of goods - see, e.g., Campa and Goldberg (2001) and Klein et al. (2003).

Portugal provides an example of a country that, in the 1970s and in the 1980s, actively tried to manage the exchange rate. Prior to the accession to the European Economic Community (EEC) in 1986, Portugal adopted a crawling peg in an effort not to lose competitiveness with regard to similar Spanish products. Joining the Exchange Rate Mechanism (ERM) in 1992, and then the European Monetary Union in 1999, therefore implied a drastic change in the behaviour of Portugal's effective exchange rate, not only because its nominal value with respect to other euro area countries could no longer be adjusted, but also because the evolution of the European Single Market, alongside the common currency, biased Portuguese trade towards European countries, especially Spain ${ }^{1}$.

This change in trade patterns in turn implies that effective exchange rates should be computed on the basis of time-varying weights - see, for example, Bayoumi et al. (2005). One difficulty with the computation of effective exchange rates is that the choice of the trade weights is not unique. In this paper we shall make use of the four basic sets of weights employed in the literature: bilateral export shares, bilateral import shares, bilateral trade shares (exports plus imports) and double-weighting schemes that account for competition from third countries. This and other issues in the computation of effective exchange rates have been the subject of a vast literature see, e.g., Turner and Van't dack (1993), Buldorini et al. (2002), Bennett and Zarnic (2008) and references therein. Another important issue is whether one can use an aggregate exchange rate index to discuss the economic performance, or whether one should use sectoral indexes. Several papers have shown that when the importance of the trading partners varies across sectors, sector-specific exchange rates may be more informative as indicators of industries' competitiveness than aggregate exchange rate indexes - see, among others, Campa and Goldberg (2001) and Gourinchas (1999).

According to our computations, between 1988 and 2006, the Portuguese aggregate real effective exchange rate appreciated more than $20 \%$. This appreciation may have had a significant impact on the Portuguese labour market, similarly to what happened in other countries. For example, Gourinchas (1999) estimated that a 1\% real appreciation of the French franc eliminated $0.95 \%$ of jobs in the tradable sectors in the following two years. Can this sort of result be found in Portuguese data? Studies of Portuguese exports - e.g., Cabral (2004) and Cabral and Esteves (2006) - have found evidence that declining competitiveness of Portuguese firms has contributed to the weak performance of Portuguese exports in recent years. Although other, qualitative, 
aspects of competitiveness are certainly important, the real exchange rate is a leading candidate to take responsibility for, at least some of, this loss of competitiveness.

The purpose of this paper is therefore to compare the evolution and evaluate the usefulness of alternative effective exchange rate indexes for the Portuguese economy. In particular, we compute sector-specific effective exchange rates and compare their patterns over time with the aggregate effective real exchange rates ${ }^{2}$. In section 2 we describe the main features of Portuguese aggregate exchange rate indexes and international trade patterns in the period 19882006. In section 3 we present sector-specific effective exchange rate indexes and compare their behaviour with that of aggregate indexes. In section 4 we assess the informative content of sector-specific real exchange rate indexes, relative to aggregate indexes, by estimating their effect on employment. Section 5 concludes.

\section{Aggregate exchange rate indexes}

Aggregate exchange rate indexes synthesize information on bilateral exchange rates and, therefore, may be useful indicators of the competitiveness of domestic production in the international context. In this section, we present several aggregate effective exchange rate indexes for the Portuguese economy and discuss their behaviour.

Our data begins in 1988, two years after Portugal (and Spain) joined the EEC and four years before Portugal joined the ERM. We construct nominal and real effective exchange rates for Portugal until 2006. Real exchange rates are more informative than nominal exchange rates about trade competitiveness when inflation differentials between trading partners are significant, which was the case for the Portuguese economy in the period of our analysis. There are several measures of relative prices and costs that may be used to deflate nominal effective exchange rates. The relative export price is the most used measure of relative prices in the computation of real effective exchange rates (Turner and Van't dack, 1993). However, relative export prices have some drawbacks. In the first place, international competition tends to erode differences in export prices across countries. In the second place, the relative export price does not provide an accurate measure of a country's competitiveness as it focuses exclusively on the goods that are actually traded. Finally, export prices, which are not indexes, are inconsistent with the logic of double-weighting effective exchange rates. Industrial producer prices are also used as a measure of relative prices. However, they exclude important sectors, their construction differs across countries and their statistical quality is dubious. The consumer price index is another measure widely used to deflate exchange rates (Bennett and Zarnic, 2008). Consumer price indexes are based on similar baskets of goods, being comparable across countries. Additionally, consumer price indexes are available for a large number of countries and for a large time span. These are the reasons why we chose to use consumer price indexes in our computation of exchange rate indexes. However, consumer price indexes include goods and services that are not internationally tradable whereas capital goods, which are tradable, are excluded. In our analysis we do not consider cost indicators, such as labour unit costs, to construct real exchange rate indexes because they are available for a small number of countries and for a rather short period - for a description of cost indicators see, for example, Turner and Van't dack (1993).

Data for nominal exchange rates, defined as national currency per US dollar at the end of the period, and for the consumer price index are from the IMF International Financial Statistics database $^{3}$. The country weights in the exchange rate indexes are based on data from OECD's STAN bilateral trade database (OECD, 2008) ${ }^{4}$.

2 The aggregate and sector-specific effective real exchange rates are available at http://www3.eeg.uminho.pt/economia/nipe/docs/2009./DATA_NIPE_WP_13_2009.xls 3 For Germany the source of the data was OECD.STAT. Data prior to 1991 referring to West Germany have been linked to the data from 1991 onwards covering unified Germany. Nominal exchange rate data for Taiwan was collected from the Statistical Bureau of the Republic of China (http://eng.stat.gov.tw).

4 For further details and access to the data, consult the webpage at http://www.oecd.org/sti/stan/. 
We compute the effective exchange rate indexes as geometrically weighted averages of bilateral exchange rates ${ }^{5}$. The real effective exchange rate index at time $t, l_{t}$, is given by the following formula:

$I_{t}=\prod_{j=1}^{N(t)}\left(\operatorname{rer}_{t}\right)^{\mathcal{W}_{j, t}}$

where

$\operatorname{rer}_{t}=\frac{e_{j, t} p_{j, t}}{p_{t}}$

is the bilateral real exchange rate between Portugal and country $j, e_{j, t}$ is the price of foreign currency $j$ in terms of escudos ${ }^{6}$ at time $t, p_{t}$ and $p_{j, t}$ are consumer price indexes for the Portuguese economy and for economy $j, N(t)$ is the number of foreign currencies in the index at time $t$ and $w_{j, t}$ is the weight of currency $j$ in the index at time $t$, with $\sum_{j} w_{j, t}=1$. An increase in the value of this index corresponds to a real depreciation of the Portuguese currency. The base of the index is the year 2000 .

In the last two decades, Portuguese international trade patterns changed significantly, both in terms of export destinations and import origins. Table 1 shows the percentage change in the shares of a group of countries in Portuguese exports and imports between 1988 and 2006. This group of countries contains Portugal's most important trade partners - accounting for at least $0.5 \%$ of Portuguese exports or imports in either 1988 or 2006 - for which individual data is available in OECD's STAN database ${ }^{7}$. The most striking development during this period was the emergence of Spain as the main trade partner: between 1988 and 2006, the share of Portuguese exports to Spain increased from $11.5 \%$ to $26.5 \%$ and the share of Portuguese imports from Spain increased from $13.1 \%$ to $28.9 \%$. Germany and France stand, respectively, as the second and third main trade partners. The decrease of UK export and import shares should also be noticed. The share of exports to the euro area increased from $57.8 \%$ to $63.3 \%$ and the share of imports from the euro area increased from $59.5 \%$ to $65.1 \%$. Despite this, the share of Portuguese exports to OECD countries decreased from $90.7 \%$ in 1998 to $82.2 \%$ in 2006, and imports from OECD registered a similar decrease.

If the weights in the effective exchange rate formulas ideally should reflect the degree to which producers in the countries considered in the index compete with domestic producers, then the changes in the importance of trade partners described above should be taken into account in the computation of effective exchange rate indexes. In addition, although fairly similar in most cases, some countries' export and import shares are very different. For example, in 2006, exports to the US represented $4.3 \%$ of Portugal's exports, but imports from that country were only $1.5 \%$ of Portugal's imports. Therefore, the computation of the weights, $w$, associated with each bilateral exchange rate will yield different results according to whether one bases the computation on

5 For a detailed explanation on the construction of effective exchange rates see, e.g., Buldorini et al. (2002). For a detailed description of aggregate trade-weighted exchange rates for the US economy constructed by the Board of Governors of the Federal Reserve System go to http://www.federalreserve.gov/releases/h10/ summary. The construction of the Bank of Portugal's current effective exchange rate index for Portugal is presented in Gouveia and Coimbra (2004); the previous index is presented in Vidal and Reis (1994). 6 In our computations, after 1998, we use the fixed parity relative to the euro: 200.482 .

7 A notable absence from Table 1 is Angola, which has gained importance in the context of Portugal's international trade in recent years. 
Table 1 - Shares in Portugal's trade

\begin{tabular}{|c|c|c|c|c|c|c|}
\hline \multirow[b]{2}{*}{ Partner } & \multicolumn{3}{|c|}{ Exports } & \multicolumn{3}{|c|}{ Imports } \\
\hline & 1988 & 2006 & $\Delta(p p)$ & 1988 & 2006 & $\Delta(p p)$ \\
\hline Austria & 1.1 & 0.5 & -0.6 & 0.8 & 0.6 & -0.1 \\
\hline Belgium-Luxembourg & 3.2 & 3.2 & 0.0 & 4.1 & 2.9 & -1.2 \\
\hline Czech Republic & 0.0 & 0.4 & 0.4 & 0.0 & 0.5 & 0.5 \\
\hline Canada & 0.9 & 0.4 & -0.5 & 1.0 & 0.2 & -0.8 \\
\hline Denmark & 2.3 & 0.7 & -1.6 & 0.9 & 0.6 & -0.3 \\
\hline Finland & 1.4 & 0.7 & -0.8 & 0.6 & 0.4 & -0.2 \\
\hline France & 15.2 & 11.9 & -3.2 & 11.7 & 8.1 & -3.6 \\
\hline Germany & 14.7 & 12.8 & -1.9 & 14.7 & 13.1 & -1.6 \\
\hline Iceland & 0.1 & 0.0 & 0.0 & 0.7 & 0.1 & -0.6 \\
\hline Ireland & 0.5 & 0.5 & 0.0 & 0.3 & 0.9 & 0.6 \\
\hline Italy & 4.1 & 3.9 & -0.3 & 9.2 & 5.6 & -3.7 \\
\hline Japan & 0.7 & 0.3 & -0.4 & 3.6 & 1.0 & -2.6 \\
\hline Mexico & 0.0 & 0.4 & 0.4 & 0.5 & 0.5 & 0.0 \\
\hline Korea & 0.2 & 0.1 & -0.1 & 0.3 & 0.6 & 0.2 \\
\hline Netherlands & 5.9 & 3.0 & -2.9 & 4.8 & 4.4 & -0.4 \\
\hline Norway & 1.7 & 0.3 & -1.4 & 1.0 & 1.3 & 0.3 \\
\hline Poland & 0.0 & 0.6 & 0.6 & 0.1 & 0.6 & 0.5 \\
\hline Spain & 11.5 & 26.5 & 15.0 & 13.1 & 28.9 & 15.8 \\
\hline Sweden & 4.0 & 1.1 & -2.9 & 1.9 & 0.9 & -1.0 \\
\hline Switzerland & 2.2 & 0.8 & -1.4 & 2.4 & 0.7 & -1.7 \\
\hline Turkey & 0.1 & 0.6 & 0.5 & 0.2 & 0.9 & 0.7 \\
\hline United Kingdom & 14.3 & 6.6 & -7.7 & 8.3 & 4.0 & -4.4 \\
\hline United States & 5.9 & 6.1 & 0.2 & 4.3 & 1.5 & -2.8 \\
\hline Argentina & 0.0 & 0.1 & 0.1 & 0.8 & 0.2 & -0.7 \\
\hline Brazil & 0.2 & 0.7 & 0.5 & 1.6 & 2.3 & 0.7 \\
\hline South Africa & 0.3 & 0.2 & -0.1 & 0.6 & 0.4 & -0.3 \\
\hline Thailand & 0.1 & 0.1 & 0.0 & 0.6 & 0.2 & -0.4 \\
\hline China & 0.3 & 0.6 & 0.3 & 0.4 & 1.4 & 1.1 \\
\hline Russia (Federation of) & 0.0 & 0.3 & 0.3 & 0.0 & 1.2 & 1.2 \\
\hline Singapore & 0.1 & 2.0 & 1.9 & 0.1 & 0.1 & 0.0 \\
\hline Total & 91.0 & 85.3 & -5.7 & 88.6 & 83.9 & -4.7 \\
\hline Euro Area (13) & 57.8 & 63.3 & 5.5 & 59.5 & 65.1 & 5.6 \\
\hline EU25 & 78.5 & 73.3 & -5.2 & 70.7 & 72.0 & 1.3 \\
\hline OECD & 90.7 & 82.2 & -8.5 & 85.1 & 78.5 & -6.6 \\
\hline
\end{tabular}

Notes: The values presented are the shares of Portugal's exports (imports) that went to (came from) each partner. $\Delta(\mathrm{pp})$ stands for change in percentage points between 1988 and 2006. 
Aggregate and sector-specific exchange rate indexes for the Portuguese economy
Fernando Alexandre/Pedro Bação/ João Cerejeira/Miguel Portela

export shares, on import shares, or on some combination of the two. In this paper we will present effective exchange rate indexes computed using export, import and "trade" weights, i.e., one effective exchange rate index will use weights based on export shares:

$w_{\exp , j, t}=\frac{X_{j, t}}{\sum_{i=1}^{N(t)} X_{i, t}}$

another index will use weights based on import shares:

$w_{i m p, j, t}=\frac{M_{j, t}}{\sum_{i=1}^{N(t)} M_{i, t}}$

and the trade-weighted index will employ the average of both shares:

$w_{\text {tra }, j, t}=0.5\left(w_{\text {exp }, j, t}+w_{i m p, j, t}\right)$

In the formulas, $X_{j, t}$ stands for Portuguese exports to country $j$ and $M_{j, t}$ is imports from country $j$ to Portugal (in year $t$ ). The indexes will be denoted FXEXp, FXImp and FXTrade, respectively. Implicitly, these weights assume that exports from one country to another compete only with the importing country's production. By including additional information in the computation of the weights, it is possible to produce effective exchange rate indexes that attempt to take into account the effect of third-party competition. In order to account for such effects, we follow Turner and Van't dack (1993), who propose that the weight given to j's currency in the doubleweighted effective index be defined as:

$w_{d w, j, t}=\left(\frac{M_{j, t}}{X_{j, t}+M_{j, t}}\right) w_{i m p, j, t}+\left(\frac{X_{j, t}}{X_{j, t}+M_{j, t}}\right) w_{X d w, j, t}$

The factor $w_{X d w, j, t}$ is given by:

$w_{X d w, j, t}=\left(\frac{X_{j, t}}{\sum_{l=1}^{N(t)} X_{l, t}}\right)\left(\frac{\gamma_{j}}{\gamma_{j}+\sum_{h \neq z} X_{j, t}^{h}}\right)+\sum_{k \neq j}\left(\frac{X_{k, t}}{\sum_{l=1}^{N(t)} X_{l, t}}\right)\left(\frac{X_{k, t}^{j}}{\gamma_{k}+\sum_{h \neq z} X_{k, t}^{h}}\right)$

where $X_{j, t}^{h}$ stands for the exports to country $j$ from country $h$, with $X_{j, t}^{z}=X_{j, t}, \sum_{l=1}^{N(t)} X_{l, t}$ are total exports from country $z$ (Portugal in the current analysis), and $\gamma_{j}$ is the domestic production of country $j$ for its home market ${ }^{8}$. The exports from country $z$ compete in foreign markets indexed by $k$, together with the domestic production and the exports from other foreign producers indexed 


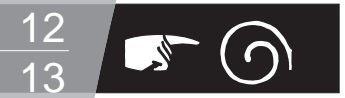

by $h$. Concerning competition in the Rest of the World (ROW), we assume as in Esteves and Reis (2006:4) that "exporters compete against each other in this ROW aggregate but not with the ROW producers".

\section{Figure 1 - Currency weights in the aggregate exchange rate index (FXTrade)}

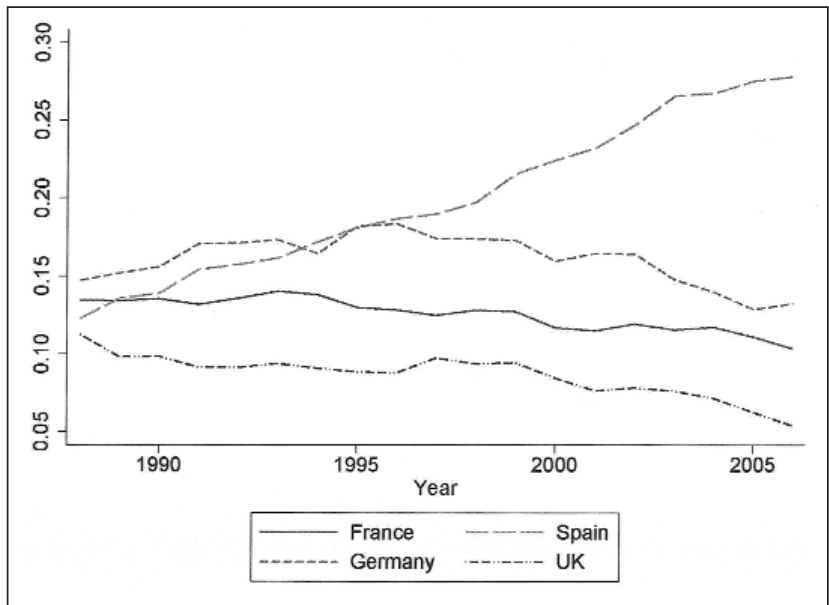

In Figure 1 we can see the evolution of selected bilateral exchange rate weights used in the computation of the FXTrade exchange rate index (the weights for the other indexes are similar). The four series depicted correspond to Portugal's main trade partners - compare Table 1. The evolution of the weights shows the importance of using time-varying data for currency weights in the construction of exchange rate indexes that aim at measuring the competitiveness of domestic firms in international trade. In fact, in Figure 1 it is clear that the weights can change substantially: we can see the significant and steady increase in the weight of the Spanish currency and the decrease in the weight of the English pound. The weights given to France and Germany have oscillated around a slightly declining trend.

Figure 2 shows the behaviour of different measures of the aggregate effective real exchange rate described above, using all 52 trade partners for which there is data in STAN, and also FXTradeDW: the trade-weighted index using the group of 25 trade partners $^{9}$ and 27 third-market competing economies ${ }^{10}$. All four measures display a very similar evolution, suggesting that the choice of weights has little impact in the Portuguese case.

Figure 3 shows the evolution of measures of the aggregate effective real exchange rate computed using different country sets. One measure (FXTradeBP) was computed by the Portuguese central bank and is available only since $1999^{11}$. The other three measures of the real

9 Trade partners used in the computation of the double-weighted exchange rate: Australia, Austria, Belgium, Czech Republic, Canada, Denmark, Finland, France, Germany, Great Britain, Greece, Hungary, Iceland, Ireland, Italy, Japan, Netherlands, Norway, Poland, Slovakia, South Korea, Spain, Sweden, Switzerland, United States of America.

10 Third-countries competing economies used in the computation of the double-weighted exchange rate: Argentina, Brazil, Bulgaria, Chile, China, Chinese Taipei, Cyprus, Estonia, Hong Kong, India, Indonesia, Israel, Latvia, Lithuania, Malaysia, Malta, Mexico, New Zealand, Philippines, Romania, Singapore, Slovenia, South Africa, Rest of the World, Russia, Thailand, Turkey.

11 Available at http://www.bportugal.pt/EstatisticasWEB. 
Aggregate and sector-specific exchange rate indexes for the Portuguese economy
Fernando Alexandre/Pedro Bação/

João Cerejeira/Miguel Portela

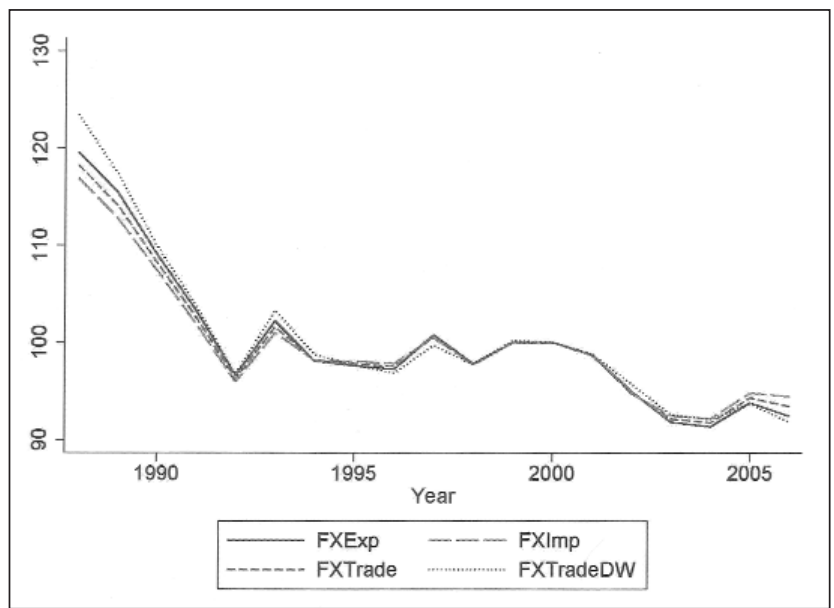

Figure 3 - Aggregate real exchange rates: alternative country sets

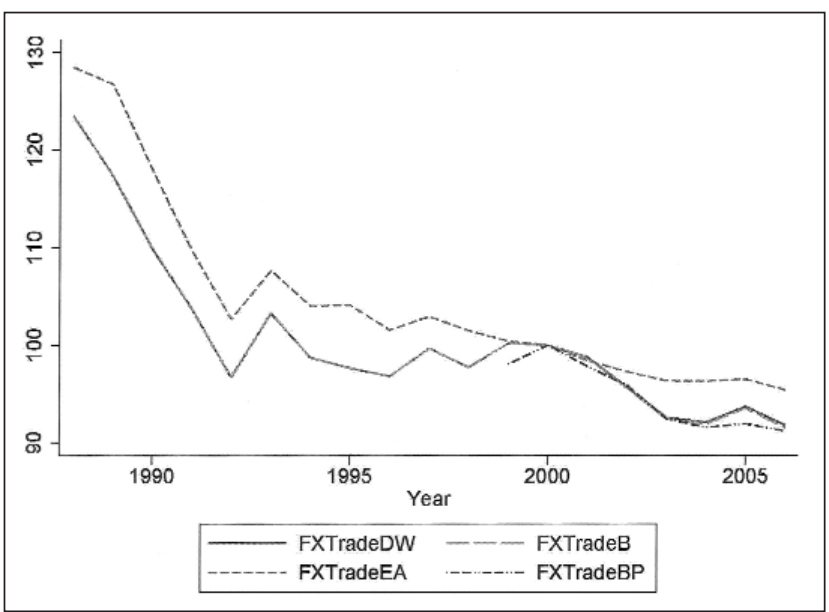

effective exchange rate were computed by us: FXTradeEA (using the thirteen countries first to join the euro), FXTradeB (using only the group of 30 countries with export or import shares larger than $0.5 \%$ in either 1988 or 2006 - recall Table 1) and FXTradeDW (using the group of 25 trade partners listed in Footnote 9 and 27 third-market competing economies listed in Footnote $10-$ also shown in Figure 2).

The four measures computed by us (the three in Figure 3 and FXTrade, shown in Figure 2) present a broadly similar behaviour. Nevertheless, the global index (FXTrade) shows an overall 
smaller decline than the other indexes. The gap between this and the other two indexes was especially notorious in the early and mid 1990s: the sequence of exchange rate adjustments that followed the ERM crisis appears to have had less impact on the global index than on the indexes that depend more heavily on European countries.

\section{Figure 4 - Real and nominal effective exchange rate indexes against the euro (13)}

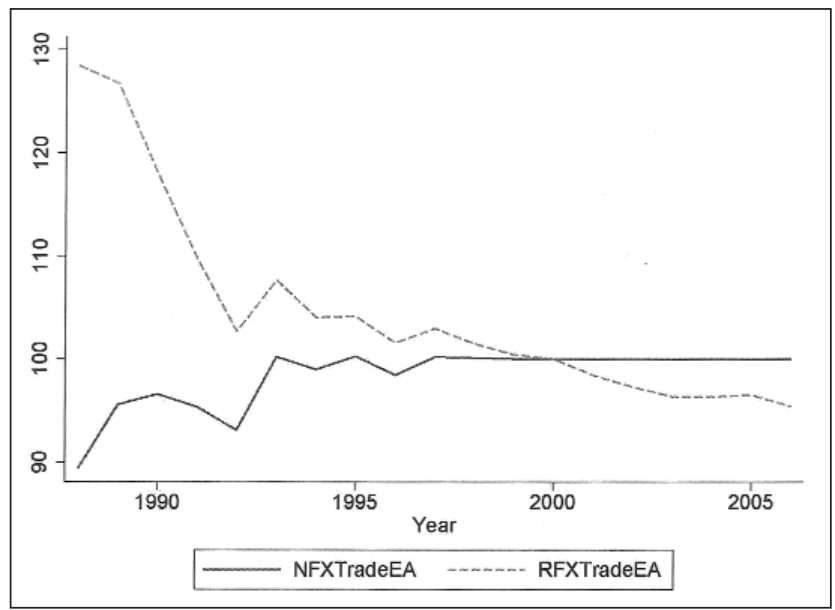

In Figure 4 we compare the evolution of the nominal (NFXTradeEA) and real (RFXTradeEA) aggregate effective exchange rates of the Portuguese currency against the currencies of the first thirteen countries to adopt the euro. Figure 4 shows that the nominal index has been more stable than the real index. It also shows that the nominal index may present a distorted picture of the evolution of competitiveness. In fact, despite the nominal depreciation before the birth of the euro, in real terms there was a large appreciation of the Portuguese currency. Most of the appreciation occurred between 1988 and 1992. This period was followed by small variations in the real exchange rate until the Portuguese escudo joined the euro. The period since then has again been characterized by a real appreciation, which amounted to approximately $7 \%$. The inflation differential relative to the trade partners is thus an important feature of the Portuguese economy during this period.

\section{Sector-specific real exchange rates}

Aggregate exchange rate indexes such as those analysed in the previous section may be useful summaries of the evolution of domestic firms' competitiveness. However, since the importance of trading partners varies across sectors, and the export destinations of an industry may be very different from the import origins of that same sector, sector-specific exchange rate indexes may be more informative than aggregate indexes concerning the evolution of industry competitiveness - see, e.g., Goldberg (2004).

In this section we present sector-specific exchange rates for 21 sectors, classified according to an industry classification based upon ISIC Rev. $3^{12}$. A complete list of the sectors may be found in Table 6 in the Appendix.

12 In this work, as mentioned above, we use the STAN Bilateral Trade Database, which follows an industry classification based upon ISIC Rev. 3. 
Aggregate and sector-specific exchange rate indexes for the Portuguese economy
Fernando Alexandre/Pedro Bação/ João Cerejeira/Miguel Portela

\begin{tabular}{|c|c|c|c|c|c|c|c|c|c|c|c|c|c|c|}
\hline \multicolumn{15}{|c|}{ Shares in Portugal's exports per sector (\%) } \\
\hline & & \multicolumn{2}{|c|}{ Spain } & \multicolumn{2}{|c|}{ Germany } & \multicolumn{2}{|c|}{ France } & \multicolumn{2}{|c|}{ UK } & \multicolumn{2}{|c|}{ Euro Area (13) } & \multicolumn{2}{|c|}{ EU 25} & OECD \\
\hline Industry & IC & 1988 & 2006 & 1988 & 2006 & 1988 & 2006 & 1988 & 2006 & 1988 & 2006 & 1988 & 2006 & 19882006 \\
\hline $\begin{array}{l}\text { Textiles, text. } \\
\text { prod., leather } \\
\text { and footwear }\end{array}$ & 4 & 3.46 & 20.89 & 19.53 & 12.77 & 16.31 & 15.73 & 17.91 & 12.48 & 54.31 & 64.40 & 85.04 & 82.23 & $97.30 \quad 90.73$ \\
\hline $\begin{array}{l}\text { Motor Vehicles, } \\
\text { trailers and } \\
\text { semi-trailers }\end{array}$ & 20 & 31.18 & 17.00 & 1.49 & 30.56 & 37.97 & 20.83 & 9.84 & 9.44 & 86.41 & 78.59 & 96.55 & 92.29 & 97.6995 .40 \\
\hline $\begin{array}{l}\text { Food products, } \\
\text { beverages and } \\
\text { tobacco }\end{array}$ & 3 & 10.98 & 25.24 & 4.78 & 2.61 & 14.50 & 11.29 & 9.66 & 5.87 & 51.37 & 59.55 & 65.29 & 67.62 & 82.6175 .81 \\
\hline
\end{tabular}

\begin{tabular}{|c|c|c|c|c|c|c|c|c|c|c|c|c|c|c|c|}
\hline $\begin{array}{l}\text { Radio, television } \\
\text { and commu- } \\
\text { nication equip. }\end{array}$ & 18 & 8.96 & 7.91 & 44.10 & 22.00 & 16.08 & 3.88 & 11.54 & 2.88 & 80.89 & 46.00 & 94.00 & 50.14 & 96.94 & 63.42 \\
\hline $\begin{array}{l}\text { Machinery and } \\
\text { equipment }\end{array}$ & 15 & 16.52 & 20.54 & 13.80 & 18.65 & 8.27 & 10.58 & 7.71 & 4.29 & 48.20 & 58.09 & 57.87 & 66.32 & 78.85 & 75.09 \\
\hline \multicolumn{16}{|c|}{ Shares in Portugal's imports per sector (\%) } \\
\hline & & \multicolumn{2}{|c|}{ Spain } & \multicolumn{2}{|c|}{ Germany } & \multicolumn{2}{|c|}{ France } & \multicolumn{2}{|c|}{ UK } & \multicolumn{2}{|c|}{ Euro Area (13) } & \multicolumn{2}{|c|}{ EU 25} & \multicolumn{2}{|c|}{ OECD } \\
\hline Industry & IC & 1988 & 2006 & 1988 & 2006 & 1988 & 2006 & 1988 & 2006 & 1988 & 2006 & 1988 & 2006 & 1988 & 2006 \\
\hline $\begin{array}{l}\text { Textiles, text. } \\
\text { prod., leather } \\
\text { and footwear }\end{array}$ & 4 & 9.92 & 35.26 & 24.09 & 7.15 & 14.17 & 8.63 & 6.53 & 2.32 & 72.61 & 75.18 & 82.05 & 78.89 & 87.35 & 81.67 \\
\hline
\end{tabular}

Motor Vehicles,

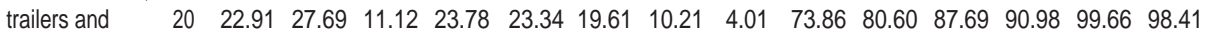
semi-trailers

Food products,

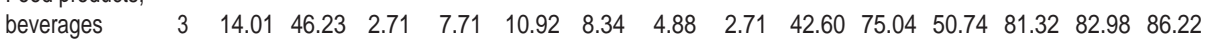
and tobacco

Radio, television

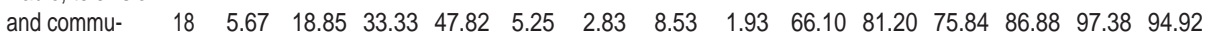
nication equip.

Machinery and equipment

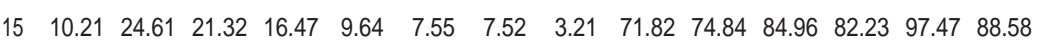

Notes: These are the shares of Portugal's exports and imports per sector that go to/come from the destinations/origins in the columns. IC stands for OECD industry classification.

Table 2 shows the share of Portuguese exports (imports) that flow to (from) the countries indicated in the columns, for the most important sectors ranked by weight in total exports (imports) in $2006^{13}$. In 2006 Spain stands out as an important export destination for all sectors presented, with export

13 See Tables 7 and 8 in the Appendix for the ranking of sectors by their weight in exports and in imports, respectively. 
shares varying between $8 \%$ for "Radio, television and communication equipment", and $25 \%$ for "Food products, beverages and tobacco". On the other hand, in 2006 Portugal bought from Spain $35 \%$ and $46 \%$ of its imports of "Textiles, textile products, leather and footwear" and "Food products, beverages and tobacco", respectively. In 2006 Germany was the most important destination of "Motor vehicles, trailers and semi-trailers", buying $31 \%$ of Portugal's exports of these goods. However, for "Food products, beverages and tobacco", Germany was only a residual destination with a $3 \%$ share of total exports. Table 2 also shows that the euro area's (13) share in "Radio, television and communication equipment" exports (46\%) is much lower than its share in "Motor vehicles, trailers and semi-trailers" exports (79\%). Another striking example of the difference in the weight of trade partners across sectors is given by the comparison between the OECD share in "Motor vehicles, trailers and semi-trailers" exports (95\%) and its share in "Radio, television and communication equipment" exports (63\%) - Singapore, in 2006, accounted for $25 \%$ of the exports of that sector. These differences imply that exchange rate movements will affect competitiveness differently in each sector and should, therefore, be weighted differently in the computation of sector-specific exchange rates, to which we now turn.

Following the approach used in the computation of aggregate exchange rate indexes, we consider three sector-specific real exchange rate measures which differ in the weights given to bilateral exchange rates and sector-specific real exchange rate indexes based on doubleweighting schemes. The weights depend on the foreign countries' shares of Portugal's exports and imports for each of the 21 sectors considered in our analysis. The formulas used in computing effective exchange rates for sector $i$ are:

(1) export-weighted:

$$
F X \operatorname{Exp}_{i, t}=\prod_{j=1}^{N(t)}\left(\operatorname{rer}_{j, t}\right) w_{\text {exp }, j, t}^{(i)}
$$

where

$w_{\mathrm{exp}, j, t}(i)=\frac{X_{j, t}(i)}{\sum_{j} X_{j, t}(i)}$

(2) import-weighted

$F X \operatorname{Imp}_{i, t}=\prod_{j=1}^{N(t)}\left(\operatorname{rer}_{j, t}\right) w_{i m p, j, t}^{(i)}$

where

$w_{i m p, j, t}(i)=\frac{M_{j, t}(i)}{\sum_{j} M_{j, t}(i)}$

(3) trade-weighted

$F X \operatorname{Trade}_{i, t}=\prod_{j=1}^{N(t)}\left(\operatorname{rer}_{j, t}\right) w_{\text {ira.j,t }}^{(i)}$

where

$$
w_{t r a, j, t}(i)=0.5\left(\frac{X_{j, t}(i)}{\sum_{j} X_{j, t}(i)}+\frac{M_{j, t}(i)}{\sum_{j} M_{j, t}(i)}\right)
$$


Aggregate and sector-specific exchange rate indexes for the Portuguese economy
Fernando Alexandre/Pedro Bação/ João Cerejeira/Miguel Portela

In the formulas above, rer $_{j, t}$ stands for the bilateral real exchange rates of each of Portugal's trading partner (indexed by $j$ ).

Additionally, we computed exchange rate weights in order to include information that would allow us to take into account sectoral third-party competition. As before, we followed Turner and Van't dack (1993) and defined the weight given to country j's currency in the double-weighted effective index as:

$w_{d w, j, t}(i)=\left(\frac{M_{j, t}(i)}{X_{j, t}(i)+M_{j, t}(i)}\right) w_{i m p, j, t}(i)+\left(\frac{X_{j, t}(i)}{X_{j, t}(i)+M_{j, t}(i)}\right) w_{X d w, j, t}(i)$

where $w_{X d w, j, t}(i)$ is defined as:

$w_{X d w, j, t}(i)=\left(\frac{X_{j, t}(i)}{\sum_{l=1}^{N(t)} X_{l, t}(i)}\right)\left(\frac{\gamma_{j}(i)}{\gamma_{j}(i)+\sum_{h \neq z} X_{j, t}^{h}(i)}\right)+\sum_{k \neq j}\left(\frac{X_{k, t}(i)}{\sum_{l=1}^{N(t)} X_{l, t}(i)}\right)\left(\frac{X_{k, t}^{j}(i)}{\gamma_{k}(i)+\sum_{h \neq z} X_{k, t}^{h}(i)}\right)$

Inflation differentials are accounted for by the consumer price index - see equation (2). It would seem more appropriate to use sectoral price indexes. However, we do not have access to that sort of data. As before, an increase in the value of these indexes implies a real depreciation of the Portuguese currency.

Although the weights of the different currencies vary significantly across sectors, the Portuguese industry-specific effective exchange rates are strongly correlated with aggregate exchange rate indexes. Table 3 shows ten sets of correlations of exchange rate indexes - see notes on Table 3 - and the number of sectors in the different levels of correlation. In fact, when using trade weights (that is, the average of export and import shares), Table 3 shows that in only 2 of the 21 sectors is the correlation between the industry-specific and the aggregate exchange rate index below 0.9 (column 3). This number increases to 4 (column 2) when imports are used as weights. The different industry indexes are also highly correlated between them. In 16 of the 21 sectors the correlation between the export-based and the import-based indexes is above 0.9 (column 8).

\begin{tabular}{l|c|c|c|c|c|c|c|c|c|c}
\hline Table 3 - Correlations between exchange rate indexes \\
\hline & $\mathbf{( 1 )}$ & $\mathbf{( 2 )}$ & $\mathbf{( 3 )}$ & $\mathbf{( 4 )}$ & $\mathbf{( 5 )}$ & $\mathbf{( 6 )}$ & $\mathbf{( 7 )}$ & $\mathbf{( 8 )}$ & $\mathbf{( 9 )}$ & $\mathbf{( 1 0 )}$ \\
\hline corr $\geq 0.90$ & 18 & 17 & 19 & 20 & 18 & 18 & 20 & 16 & 18 & 20 \\
\hline $0.90>$ corr $\geq 0.80$ & 1 & 3 & 1 & 0 & 3 & 3 & 1 & 2 & 3 & 1 \\
\hline $0.80>$ corr $\geq 0.70$ & 2 & 0 & 0 & 0 & 0 & 0 & 0 & 2 & 0 & 0 \\
\hline $0.70>$ corr & 0 & 1 & 1 & 1 & 0 & 0 & 0 & 1 & 0 & 0 \\
\hline
\end{tabular}

Notes: number of sectors in each correlation grouping out of 21 sectors. In columns (1), (2), (3), (4), (5), (6), (7), (8), (9) and (10), we have FXEXp $p_{i}$ with FXTradeDW, FXImp $p_{i}$ with FXTradeDW, FXTrade ${ }_{i}$ with FXTradeDW, FXTradeDW, with FXTradeDW, FXEXp with $_{i}$ XXTradeDW

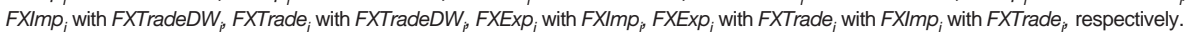

\begin{tabular}{l|c|c|c|c}
\hline Table 4 - Exchange rate indexes: percentage change between 1988 and 2006 \\
\hline & $\boldsymbol{F X E x p}_{\boldsymbol{i}}$ & $\boldsymbol{F X I m p}_{\boldsymbol{i}}$ & $\boldsymbol{F X T r a d e}_{\boldsymbol{i}}$ & $\boldsymbol{F X T r a d e D W}_{\boldsymbol{i}}$ \\
\hline Food products, beverages and tobacco & -17.8 & -16.7 & -17.2 & -24.2 \\
\hline Textiles, textile products, leather and footwear & -23.5 & -17.4 & -20.5 & -25.6 \\
\hline Chemicals excluding pharmaceuticals & -19.5 & -20.7 & -20.1 & -23.5 \\
\hline Machinery and equipment, nec & -17.4 & -24.5 & -21.0 & -26.6 \\
\hline Motor vehicles, trailers and semi-trailers & -25.4 & -26.0 & -25.7 & -26.8 \\
\hline Global & -22.7 & -19.2 & -21.0 & -25.6 \\
\hline
\end{tabular}


Given the evidence of high correlation presented above, it is not surprising that the change in the exchange rate indexes is broadly similar across industries. Table 4 shows the change in the exchange rate indexes for the 5 most important sectors ("Food products, beverages and tobacco", "Textiles, textile products, leather and footwear", "Chemicals excluding Pharmaceuticals", "Machinery and equipment, n.e.c.", and "Motor vehicles, trailers and semitrailers") and for the aggregate of 21 sectors. The same conclusion may also be drawn from the analysis of Figure 5 where sector-specific exchange rates show very similar patterns (for the graphs of the remaining sector-specific exchange rates see Figures 6, 7 and 8 in the Appendix).

\section{Figure 5 - Sector-specific exchange rates}

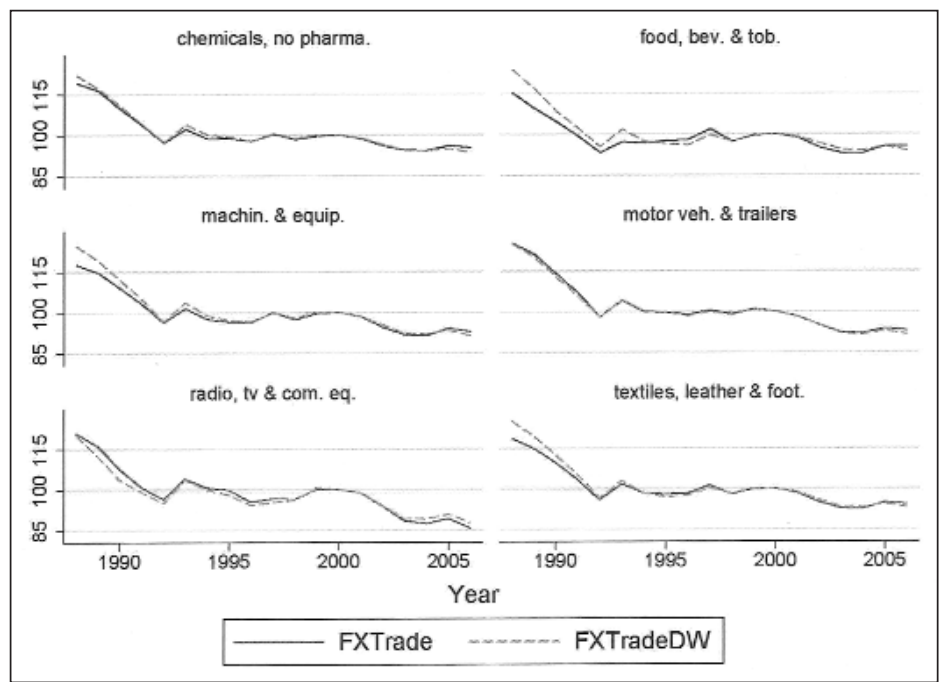

4. Aggregate versus sector-specific exchange rates indexes: an application to labour market demand

There is a growing literature on the impact of exchange rate movements on labour markets - see, e.g., Campa and Goldberg (2001) and the references therein. In particular, the wild swings of the US dollar in the 1980s have been a special focus of attention. Branson and Love (1988) estimate that the appreciation of the US dollar in the first half of the 1980s caused the loss of about 1 million jobs in US manufacturing. Using data for a sub-sample of manufacturing sectors over a similar time-period, Revenga (1992) found evidence that the appreciation of the US dollar had reduced employment in US manufacturing sectors by $4.5-7.5 \%$ on average, besides having reduced wages. Campa and Goldberg (2001) add data for the 1990s. They also find an effect of exchange rates on US manufacturing employment. However, their analysis shows that the exchange rate impact is less than previously estimated and that it is concentrated in low priceover-cost-markup industries and in industries with proportionally less college-educated workers. Similar studies have been conducted in other countries. An example already mentioned is that of Gourinchas (1999), who estimated that a 1\% appreciation of the French franc decreases tradable employment growth by $0.9 \%$ in the following two years. Another recent study is that of Ekholm et al. (2008), who conclude that the sharp appreciation of the Norwegian krone in the early 2000s explains one seventh of the total decline in manufacturing employment in that period. 
Here we will perform a similar analysis using Portuguese data. However, the goal here is not to conduct an exhaustive study of the impact of exchange rate movements on Portuguese manufacturing employment, but rather to compare the usefulness of the different exchange rate indexes discussed in the study of the issue. We use employment sector-level data, for the period 1988-2006, from the "Quadros de Pessoal" dataset provided by the Portuguese Ministry of Labour and Social Solidarity (Portugal, 2006). This dataset is based on a compulsory survey that matches all firms and establishments (with at least one employee) with their workers. In 1988, it included 122,774 firms and 1,996,933 workers, covering $43 \%$ of total employment. In 2006, it included 344,024 firms and 3,099,513 workers, covering 55\% of total employment. We aggregated the firm-level data from "Quadros de Pessoal" to obtain sector-level data for 21 manufacturing sectors, which were selected to match the International Standard Industrial Classification of all economic activities, Revision 3 (ISIC Rev. 3), as they are more exposed to foreign trade. In the 21 sectors used in the previous section we did not include non-manufacturing sectors such as "Agriculture, hunting, forestry and fishing", "Mining and quarrying", "Electricity, gas and water supply", "Scrap metal", "Waste" and the residual sector "Other". We also excluded "Coke, refined petroleum products and nuclear fuel". For a list of the 21 sectors see Table 7 in the Appendix.

To evaluate at the sector-level the effect of real aggregate and sector-specific exchange rates on employment growth we use a model based on Gourinchas (1999), specified in first-differences, with the following form:

$$
\Delta l_{i t}=\beta_{0}+\beta_{1} \Delta \log \left(\text { ExRate }_{i, t-1}\right)+\beta_{2} \Delta \text { ShareImp }_{i, t-1}+\lambda_{t}+\theta_{i}+\tau Z_{t-1}+\varepsilon_{i t}
$$

The dependent variable, $l_{i t}$, is employment (in logs), measured as total workers observed for each sector $i$ in year $t$. ExRate ${ }_{i, t-1}$ is either the lagged real effective aggregate exchange rate or sector $i$ exchange rate (in logs), as defined in the previous section ${ }^{14}$. The exchange rate is smoothed by the Hodrick-Prescott filter, which filters out the transitory component of the exchange rate. In order to account for competition from non-OECD countries (in particular, from emerging countries), we include the variable Share $I m p_{i, t-1}$, which is the share of non-OECD countries in sector $i$ OECD countries' imports. $\Delta$ denotes the first difference of the variables. The model also includes a set of time dummies, $\lambda_{t}$, in order to control for common aggregate time variant shocks, such as monetary policy shocks, and a set of sectoral dummies $\theta_{i}$. Since we specify a model in first-differences, these dummies account for sector-specific trends. Finally, $\varepsilon_{i t}$ is a white noise error term. All variables are in real terms. The model is estimated by OLS, with robust standard errors allowing for within-sector correlation.

When the model is estimated using the aggregate real effective exchange rate we cannot control for aggregate shocks using time dummies. As such, we control for aggregate shocks that may affect input prices using changes in oil prices $\left(\Delta R P O i_{t-1}\right)$, changes in the long-term interest rate $\left(\Delta L T I R_{t-1}\right)$ and changes in unit labour costs $\left(\Delta U L C_{t-1}\right)$. Additionally, we also control for business cycle effects by including changes in the logarithm of real GDP in the European Union-15 $\left(\Delta \log \left(R G D P_{t-1}\right): E U\right)$ or in the logarithm of real Portuguese GDP $\left(\Delta \log \left(R G D P_{t-1}\right): \mathrm{PT}\right)$. These control variables are included in vector $\mathbf{Z}_{t-1}$ and are lagged one year. 


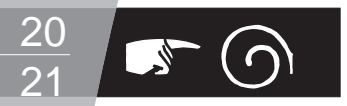

Table 5 - Sectoral employment and exchange rates: OLS regressions in first-differences

\begin{tabular}{|c|c|c|c|c|c|c|}
\hline & \multicolumn{2}{|c|}{ Aggregate } & \multicolumn{4}{|c|}{ Sector-specific } \\
\hline & (1) & (2) & (3) & (4) & (5) & (6) \\
\hline$\Delta \log \left(F X\right.$ Trade $\left.D W_{t-1}\right)$ & $\begin{array}{l}.481 \\
(.535)\end{array}$ & $\begin{array}{c}.328 \\
(.728)\end{array}$ & & & & \\
\hline$\Delta \log \left(F X T r a d e D W_{i, t-1}\right)$ & & & $\begin{array}{l}.989^{*} \\
(.542)\end{array}$ & $\begin{array}{l}.889^{* *} \\
(.448)\end{array}$ & $\begin{array}{c}5.302^{* * *} \\
(1.826)\end{array}$ & $\begin{array}{c}4.836^{* * *} \\
(1.649)\end{array}$ \\
\hline$\Delta$ Share $I m p_{i, t-1}$ & $\begin{array}{c}-.918^{\star * \star} \\
(.239)\end{array}$ & $\begin{array}{c}-.954^{* * *} \\
(.242)\end{array}$ & $\begin{array}{c}-.914^{* * *} \\
(.234)\end{array}$ & $\begin{array}{c}-.933^{\star * *} \\
(.240)\end{array}$ & $\begin{array}{c}-1.006^{* * *} \\
(.202)\end{array}$ & $\begin{array}{c}-.989^{\star \star *} \\
(.281)\end{array}$ \\
\hline$\Delta$ RPOil $_{t-1}$ & $\begin{array}{l}-.004 \\
(.044)\end{array}$ & $\begin{array}{l}-.003 \\
(.031)\end{array}$ & $\begin{array}{l}-.006 \\
(.043)\end{array}$ & $\begin{array}{l}-.007 \\
(.030)\end{array}$ & & \\
\hline$\Delta L T I R_{t-1}$ & $\begin{array}{l}-.0007 \\
(.007)\end{array}$ & $\begin{array}{l}-.002 \\
(.007)\end{array}$ & $\begin{array}{c}.001 \\
(.008)\end{array}$ & $\begin{array}{l}.0008 \\
(.007)\end{array}$ & & \\
\hline$\Delta \log \left(R G D P_{t-1}\right): \mathrm{EU}$ & $\begin{array}{c}-.228 \\
(2.104)\end{array}$ & & $\begin{array}{c}-.236 \\
(2.138)\end{array}$ & & & \\
\hline$\Delta \log \left(R G D P_{t-1}\right): \mathrm{PT}$ & & $\begin{array}{l}-.379 \\
(.950)\end{array}$ & & $\begin{array}{l}-.267 \\
(.870)\end{array}$ & & \\
\hline$\Delta U L C_{t-1}$ & $\begin{array}{r}-.0002 \\
(.004) \\
\end{array}$ & $\begin{array}{l}.0004 \\
(.005) \\
\end{array}$ & $\begin{array}{c}.002 \\
(.004) \\
\end{array}$ & $\begin{array}{c}.003 \\
(.005) \\
\end{array}$ & & \\
\hline Time dummies & no & no & no & no & yes & yes \\
\hline Sectoral dummies & no & no & no & no & no & yes \\
\hline Observations & 357 & 357 & 357 & 357 & 357 & 357 \\
\hline$R^{2}$ & .007 & .008 & .01 & .01 & .049 & .081 \\
\hline LogLikelihood & -4.083 & -3.935 & -3.575 & -3.509 & 3.627 & 9.662 \\
\hline RMSE & .247 & .247 & .247 & .247 & .246 & .25 \\
\hline
\end{tabular}

Notes: Significance levels: *: $10 \%$; **: $5 \%$; ***: $1 \%$.

The dependent variable is the change in the logarithm of sectoral employment. All regressions are estimated by OLS. RMSE is root mean squared error. The exchange rate is the filtered series obtained by the Hodrick-Prescott filter. The regressions under AGGREGATE were estimated using the aggregate exchange rate index, while the regressions under SECTOR-SPECIFIC were estimated using the sectoral exchange rate indexes.

Table 5 shows the results of the estimation of equation (16). Our results, using both EU-15 GDP and Portuguese GDP growth as control variables - columns (1) and (2) -, suggest that the aggregate exchange rate does not explain changes in employment. On the contrary, sector-specific exchange rates seem to have a significant role in the explanation of movements in employment - columns (3) to (6). Using the sector-specific exchange rate, and GDP growth for EU-15, column (3), the estimated employment-exchange rate elasticity is 0.989 . Using the Portuguese GDP growth the elasticity is slightly smaller (0.889).

In column (5) we combine sector-specific exchange rates with time dummies to control for aggregate shocks. Time dummies are preferred to aggregate controls since we can control for any common aggregate shock which is correlated with changes in sector-specific exchange rates. In this case, there is both an increase in the employment-exchange rate elasticity and in its 
significance: a $1 \%$ depreciation of the real exchange rate implies a 5.3\% increase in sectoral employment. This result is robust to the inclusion of sector-specific trends - see column (6). In addition, it is important to note that the inclusion of sector-specific exchange rates increases the precision of the estimates.

Finally, it should be stressed that our results show a negative effect of non-OECD competition on employment, with an implied elasticity in the range $0.91-1.01$.

\section{Conclusion}

The integration in the EEC, in 1986, implied structural changes in the behaviour of Portuguese real exchange rate indexes. On the one hand, changes in Portugal's international trade patterns have resulted in a significant variation in bilateral exchange rate weights in effective exchange rate indexes. On the other hand, the participation in the Exchange Rate Mechanism reduced the scope for changes in the nominal value of the escudo. However, even after the accession to the euro area, inflation differentials and fluctuations of the euro vis-à-vis other currencies still had an impact on real effective exchange rates.

These were the motivations for computing exchange rate indexes for the Portuguese economy. Exchange rate indexes depend on the group of trade-partner countries included in exchange rate indexes and on the bilateral exchange rate weights, which depend on whether we consider total trade, exports or imports. For example, between 1988 and 2006, the analysis of bilateral exchange rate weights shows an increasing weight of Spain and a decreasing weight of the United Kingdom in exchange rate indexes. After 1998, aggregate exchange rate indexes based on exports, imports and total trade exhibit very similar patterns.

Additionally, exchange rate indexes may be computed for the whole economy and for specific sectors of the economy, as the group of trade-partner countries varies between sectors. For this reason it has been argued that sector-specific exchange rates are more informative on the competitiveness of the economy. We computed exchange rate indexes for 21 sectors and concluded that Portuguese sector-specific effective exchange rates are strongly correlated between them and with aggregate exchange rate indexes.

Finally, following the literature on exchange rates and labour markets, we used employment sector-level data to evaluate the benefits of using sector-specific real exchange rates relative to aggregate exchange rate indexes. Our estimates suggest that sector-specific exchange rates are more informative than aggregate exchange rate indexes in explaining changes in manufacturing employment. We estimate that, at the sector-level, a $1 \%$ real appreciation decreases employment growth by $0.9-5.3 \%$. Our results suggest that more effort should be devoted to the construction and analysis of sector-specific exchange rate indexes. 


\section{0}

References

Amador, J.; Cabral, S.; Maria, J. R. (2007) International trade patterns over the last four decades: How does Portugal compare with other cohesion countries?, Working Papers 14/2007, Banco de Portugal.

Bayoumi, T.; Lee, J.; Jayanthi, S. (2005) New rates from new weights, IMF Working Papers 05/99, International Monetary Fund.

Bennett, H. Z.; Zarnic, Z. (2008) International competitiveness of the Mediterranean quartet: A heterogeneous-product approach, IMF Working Papers 08/240, International Monetary Fund.

Branson, W.; Love, J. (1988) U.S. manufacturing and the real exchange rate, in Marston, R. (ed.) Misalignments of exchange rates: Effects on trade and industry, Chicago, Chicago University Press, 241-275.

Buldorini, L.; Makrydakis, S.; Thimann, C. (2002) The effective exchange rates of the euro, European Central Bank Occasional Paper Series 2.

Cabral, M. H. C. (2008) Export diversification and technological improvement: Recent trends in the Portuguese economy, GEE Papers 6, Gabinete de Estratégia e Estudos - Ministério da Economia e da Inovação.

Cabral, S. (2004) A evolução recente da quota de mercado das exportações portuguesas na União Europeia, Boletim Económico, Dezembro, Banco de Portugal.

Cabral, S.; Esteves, P. S. (2006) Quotas de mercado das exportações portuguesas: Uma análise nos principais mercados de exportação, Boletim Económico, Verão, Banco de Portugal. Campa, J.; Goldberg, L. (2001) Employment versus wage adjustment and the US dollar, Review of Economics and Statistics, 83, 477-489.

Ekholm, K.; Moxnes, A.; Ulltveit-Moe, K. H. (2008) Manufacturing restructuring and the role of real exchange rate shocks: A firm level analysis, CEPR Discussion Paper 6904.

Esteves, P. S.; Reis, C. (2005) Competitividade das exportações portuguesas: Uma avaliação dos pesos da taxa de câmbio efectiva. Boletim Económico, Inverno, Banco de Portugal.

Esteves, P. S.; Reis, C. (2006) Measuring export competitiveness: Revisiting the effective exchange rate weights for the euro area countries, Working Paper 11-2006, Banco de Portugal.

Goldberg, L. (2004) Industry-specific exchange rates for the United States, Federal Reserve Bank of New York Economic Policy Review, 10, 1-16.

Gourinchas, P. (1999) Exchange rates do matter: French job reallocation and exchange rate turbulence, 1984-1992, European Economic Review, 43, 1279-1316.

Gouveia, A.; Coimbra, C. (2004) Novo índice cambial efectivo para a economia portuguesa, Boletim Económico, Dezembro, Banco de Portugal.

Klein, M. K.; Schuh, S.; Triest, R. (2003) Job creation, job destruction, and the real exchange rate, Journal of International Economics, 59, 239-265.

OECD (2008) STAN Bilateral Trade Database.

Portugal. Ministry of Social Security and Employment (1988-2006) Quadros de Pessoal. Data in magnetic medium.

Revenga, A. L. (1992) The impact of import competition on employment and wages in U.S. manufacturing, Quarterly Journal of Economics, 107, 255-284.

Turner, P.; Van't dack, J. (1993) Measuring international price and cost competitiveness, BIS Economic Papers 39, Bank for International Settlements.

Vidal, M. J.; Reis, T.B. (1994) Índice da taxa de câmbio efectiva do escudo: Estudo dos ponderadores do comércio externo e apresentação da nova metodologia, Boletim Trimestral, Junho, Banco de Portugal. 
Aggregate and sector-specific exchange rate indexes for the Portuguese economy
Fernando Alexandre/Pedro Bação/ João Cerejeira/Miguel Portela

Appendix

\section{Table 6 - List of sectors}

\begin{tabular}{l|r} 
Sector & ISIC Rev. 3
\end{tabular}

Food products, beverages and tobacco

$15-16$

Textiles, textile products, leather and footwear

$17-19$

Wood and products of wood and cork

20

Pulp, paper, paper products, printing and publishing

$21-22$

Chemicals excluding pharmaceuticals

24 , excl. 2423

\begin{tabular}{lc} 
Pharmaceuticals & 2423 \\
\hline Rubber and plastics products & 25 \\
\hline Other non-metallic mineral products & 26 \\
\hline Iron and steel & $271+2731$ \\
\hline Non-ferrous metals & $272+2732$ \\
\hline Fabricated metal products, except machinery and equipment & 29 \\
\hline Machinery and equipment, nec & 30 \\
\hline Office, accounting and computing machinery & 31 \\
\hline Electrical machinery and apparatus, nec & 32 \\
\hline Radio, television and communication equipment & 33 \\
\hline Medical, precision and optical instruments, watches and clocks & 34 \\
\hline Motor vehicles, trailers and semi-trailers & 351 \\
\hline Building and repairing of ships and boats & 353 \\
\hline Aircraft and spacecraft & $352+359$ \\
\hline Railroad equipment and transport equipment nec & $36-37$ \\
\hline Manufacturing nec & 28 \\
\hline
\end{tabular}




\section{${ }_{25}^{24}-0$}

Table 7 - Exports by sector: value (US $10^{3}$ dollars), sector share in total exports and rank

\begin{tabular}{|c|c|c|c|c|c|c|}
\hline Sector & Ex88 & $S 88$ & $R 88$ & Ex06 & S06 & R06 \\
\hline Pharmaceuticals & 88133 & 0.008 & 14 & 453816 & 0.012 & 17 \\
\hline $\begin{array}{l}\text { Office, accounting and computing } \\
\text { machinery }\end{array}$ & 66290 & 0.006 & 16 & 748174 & 0.020 & 15 \\
\hline $\begin{array}{l}\text { Radio, television and communication } \\
\text { equipment }\end{array}$ & 371430 & 0.035 & 8 & 3039757 & 0.080 & 4 \\
\hline $\begin{array}{l}\text { Medical, precision and opt. inst., } \\
\text { watches, clocks }\end{array}$ & 64578 & 0.006 & 18 & 374783 & 0.010 & 18 \\
\hline Aircraft and spacecraft & 38257 & 0.004 & 20 & 99656 & 0.003 & 20 \\
\hline Chemicals excluding pharmaceuticals & 617246 & 0.059 & 6 & 2462823 & 0.065 & 6 \\
\hline Machinery and equipment, nec & 361495 & 0.035 & 9 & 2572785 & 0.068 & 5 \\
\hline Electrical machinery and apparatus, nec & 297018 & 0.028 & 10 & 1678416 & 0.044 & 9 \\
\hline Motor vehicles, trailers and semi-trailers & 721393 & 0.069 & 5 & 5482275 & 0.144 & 2 \\
\hline $\begin{array}{l}\text { Railroad equipment and transport } \\
\text { equipment nec }\end{array}$ & 12225 & 0.001 & 21 & 188601 & 0.005 & 19 \\
\hline Rubber and plastics products & 134250 & 0.013 & 13 & 1689521 & 0.045 & 8 \\
\hline Other non-metallic mineral products & 431736 & 0.041 & 7 & 1711633 & 0.045 & 7 \\
\hline Iron and steel & 66259 & 0.006 & 17 & 1084494 & 0.029 & 14 \\
\hline Non-ferrous metals & 75396 & 0.007 & 15 & 633388 & 0.017 & 16 \\
\hline $\begin{array}{l}\text { Fabricated metal products, except mach } \\
\text { and equip }\end{array}$ & 239127 & 0.023 & 11 & 1615982 & 0.043 & 10 \\
\hline Building and repairing of ships and boats & 44271 & 0.004 & 19 & 87711 & 0.002 & 21 \\
\hline Food products, beverages and tobacco & 812261 & 0.078 & 3 & 3076193 & 0.081 & 3 \\
\hline $\begin{array}{l}\text { Textiles, textile products, leather and } \\
\text { footwear }\end{array}$ & 4245899 & 0.406 & 1 & 6657559 & 0.175 & 1 \\
\hline Wood and products of wood and cork & 731368 & 0.070 & 4 & 1582630 & 0.042 & 11 \\
\hline $\begin{array}{l}\text { Pulp, paper, paper products, printing } \\
\text { and pub }\end{array}$ & 853416 & 0.082 & 2 & 1565557 & 0.041 & 12 \\
\hline Manufacturing nec & 194072 & 0.019 & 12 & 1135634 & 0.030 & 13 \\
\hline Total exports & 10466119 & & & 37941388 & & \\
\hline
\end{tabular}

Notes: Ex stands for exports (current prices), $S$ for share and $R$ for rank; subsequent numbers stand for years. 
Aggregate and sector-specific exchange rate indexes for the Portuguese economy
Fernando Alexandre/Pedro Bação/ João Cerejeira/Miguel Portela

\begin{tabular}{|c|c|c|c|c|c|c|}
\hline Sector & Im88 & S88 & $R 88$ & Im06 & SO6 & $R 06$ \\
\hline Pharmaceuticals & 288493 & 0.020 & 15 & 2396052 & 0.046 & 8 \\
\hline $\begin{array}{l}\text { Office, accounting and computing } \\
\text { machinery }\end{array}$ & 488890 & 0.033 & 8 & 1533581 & 0.030 & 13 \\
\hline $\begin{array}{l}\text { Radio, television and communication } \\
\text { equipment }\end{array}$ & 758549 & 0.051 & 6 & 4262404 & 0.082 & 6 \\
\hline $\begin{array}{l}\text { Medical, precision and opt. inst., } \\
\text { watches, clocks }\end{array}$ & 352934 & 0.024 & 13 & 1375875 & 0.027 & 15 \\
\hline Aircraft and spacecraft & 55028 & 0.004 & 19 & 703127 & 0.014 & 18 \\
\hline Chemicals excluding pharmaceuticals & 1671470 & 0.113 & 3 & 5196197 & 0.100 & 3 \\
\hline Machinery and equipment, nec & 2312008 & 0.157 & 2 & 4469612 & 0.086 & 5 \\
\hline Electrical machinery and apparatus, nec & 463250 & 0.031 & 9 & 1865671 & 0.036 & 10 \\
\hline Motor vehicles, trailers and semi-trailers & 2706021 & 0.184 & 1 & 7176663 & 0.139 & 1 \\
\hline $\begin{array}{l}\text { Railroad equipment and transport } \\
\text { equipment nec }\end{array}$ & 53892 & 0.004 & 20 & 224804 & 0.004 & 20 \\
\hline Rubber and plastics products & 378555 & 0.026 & 12 & 1653024 & 0.032 & 12 \\
\hline Other non-metallic mineral products & 243315 & 0.017 & 17 & 995673 & 0.019 & 17 \\
\hline Iron and steel & 587824 & 0.040 & 7 & 2685929 & 0.052 & 7 \\
\hline Non-ferrous metals & 388547 & 0.026 & 10 & 1895516 & 0.037 & 9 \\
\hline $\begin{array}{l}\text { Fabricated metal products, except mach } \\
\text { and equip }\end{array}$ & 298798 & 0.020 & 14 & 1495433 & 0.029 & 14 \\
\hline Building and repairing of ships and boats & 35974 & 0.002 & 21 & 52798 & 0.001 & 21 \\
\hline Food products, beverages and tobacco & 1415829 & 0.096 & 5 & 5478461 & 0.106 & 2 \\
\hline $\begin{array}{l}\text { Textiles, textile products, leather and } \\
\text { footwear }\end{array}$ & 1546021 & 0.105 & 4 & 4588713 & 0.089 & 4 \\
\hline Wood and products of wood and cork & 62355 & 0.004 & 18 & 592207 & 0.011 & 19 \\
\hline $\begin{array}{l}\text { Pulp, paper, paper products, printing } \\
\text { and pub }\end{array}$ & 385853 & 0.026 & 11 & 1775249 & 0.034 & 11 \\
\hline Manufacturing nec & 251414 & 0.017 & 16 & 1355517 & 0.026 & 16 \\
\hline Total exports & 14745021 & & & 51772504 & & \\
\hline
\end{tabular}

Notes: $I m$ stands for imports (current prices), $S$ for share and $R$ for rank; subsequent numbers stand for years. 


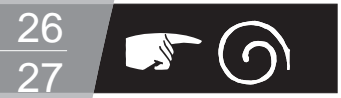

Table 9 - Aggregate real exchange rates: alternative weights

\begin{tabular}{cccccc}
\hline Years & $\boldsymbol{F X E x \boldsymbol { p }}$ & $\boldsymbol{F X I m p}$ & $\boldsymbol{F X T r a d e}$ & $\boldsymbol{F X T r a d e D W}$ \\
\hline 1988 & 119.6 & 116.9 & 118.3 & 123.5 \\
\hline 1989 & 115.4 & 112.8 & 114.1 & 117.4 \\
\hline 1990 & 109.1 & 107.4 & 108.2 & 109.9 \\
\hline 1991 & 103.3 & 101.9 & 102.6 & 103.8 \\
\hline 1992 & 96.6 & 95.9 & 96.3 & 96.7 \\
\hline 1993 & 102.2 & 101.0 & 101.6 & 103.3 \\
\hline 1994 & 98.1 & 98.1 & 98.1 & 98.7 \\
\hline 1995 & 97.6 & 98.1 & 97.8 & 97.7 \\
\hline 1996 & 97.2 & 97.8 & 97.5 & 96.8 \\
\hline 1997 & 100.8 & 100.5 & 100.6 & 99.7 \\
\hline 1998 & 97.8 & 97.7 & 97.7 & 97.7 \\
\hline 1999 & 100.0 & 100.0 & 100.0 & 100.2 \\
\hline 2000 & 100.0 & 100.0 & 100.0 & 100.0 \\
\hline 2001 & 98.7 & 98.7 & 98.7 & 98.8 \\
\hline 2002 & 94.9 & 94.7 & 94.8 & 95.7 \\
\hline 2003 & 91.8 & 92.5 & 92.1 & 92.6 \\
\hline 2004 & 91.3 & 92.2 & 91.7 & 92.1 \\
\hline 2005 & 93.8 & 94.8 & 94.3 & 93.7 \\
\hline 2006 & 92.4 & 94.5 & 93.4 & 91.8 \\
\hline
\end{tabular}

Table 10 - Aggregate real exchange rates: alternative country sets

\begin{tabular}{ccccc}
\hline Years & FXTradeB & FXTradeEA & FXTradeDW \\
\hline 1988 & 123.4 & 128.4 & 123.5 \\
\hline 1989 & 117.4 & 126.7 & 117.4 \\
\hline 1990 & 110.0 & 118.0 & 109.9 \\
\hline 1991 & 103.8 & 109.7 & 103.8 \\
\hline 1992 & 96.8 & 102.7 & 96.7 \\
\hline 1993 & 103.3 & 107.7 & 103.3 \\
\hline 1994 & 98.7 & 104.0 & 98.7 \\
\hline 1995 & 97.7 & 104.1 & 97.7 \\
\hline 1996 & 96.8 & 101.6 & 96.8 \\
\hline 1997 & 99.7 & 102.9 & 99.7 \\
\hline 1998 & 97.8 & 101.5 & 97.7 \\
\hline 1999 & 100.2 & 100.4 & 100.2 \\
\hline 2000 & 100.0 & 100.0 & 100.0 \\
\hline 2001 & 98.7 & 98.4 & 98.8 \\
\hline 2002 & 95.6 & 97.3 & 95.7 \\
\hline 2003 & 92.5 & 96.4 & 92.6 \\
\hline 2004 & 91.9 & 96.3 & 93.1 \\
\hline 2005 & 93.5 & 96.5 & 91.8 \\
\hline 2006 & 91.5 & 95.4 &
\end{tabular}


Aggregate and sector-specific exchange rate indexes for the Portuguese economy
Fernando Alexandre/Pedro Bação/

João Cerejeira/Miguel Portela

Figure 6 - Sector-specific exchange rates

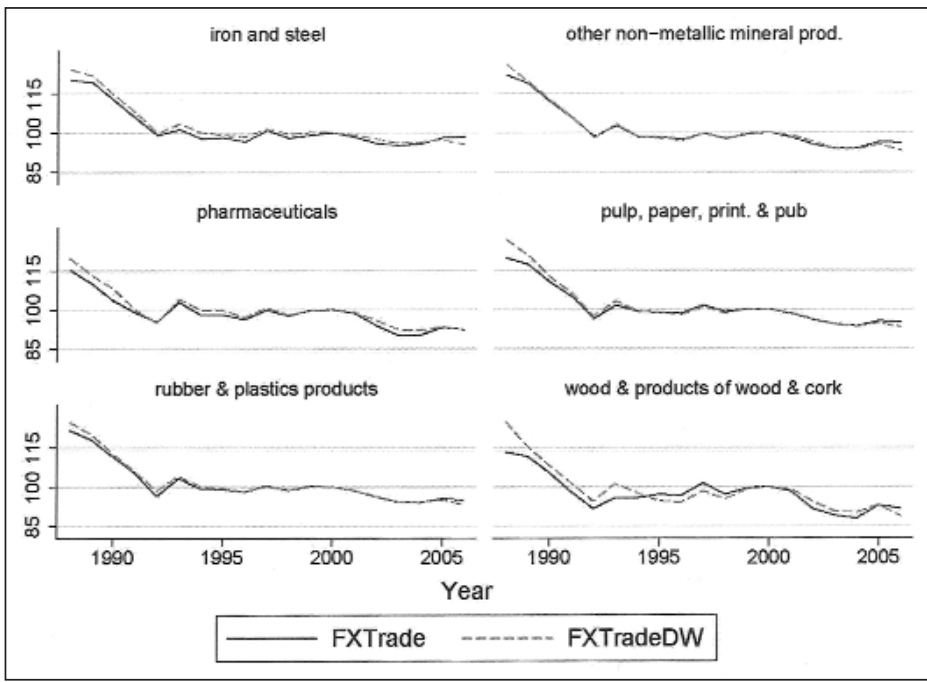

Figure 7 - Sector-specific exchange rates (continued)

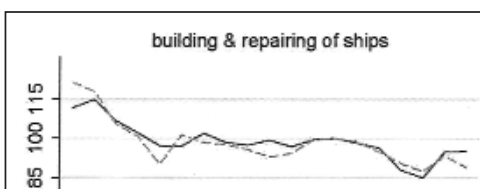

fab. metal prod., except mach \& equip
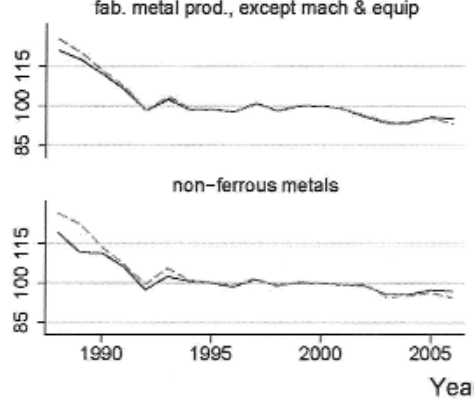

electrical machin. \& apparatus, nec

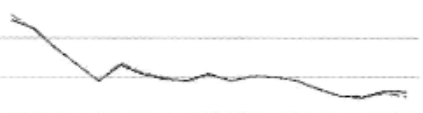

medical, precision. inst., watches

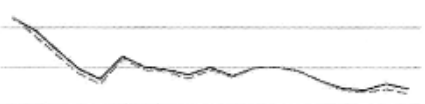

office, account. \& comput. machin.

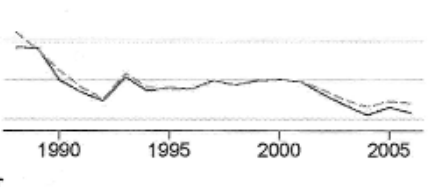




\section{NOtaS ECONÓMICAS Dezembro '09 / (6/28)}

\section{8 29}

Figure 8 - Sector-specific exchange rates (continued)

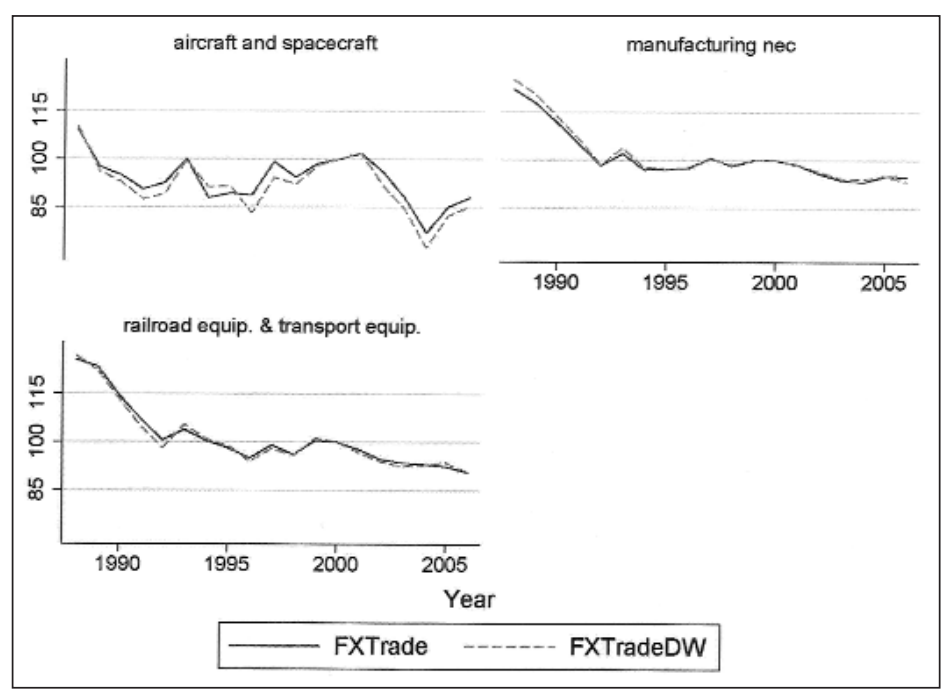

